\title{
Stem Cells and Respiratory Diseases
}

\author{
Soraia Carvalho Abreu, Tatiana Maron-Gutierrez, Cristiane Sousa Nascimento Baez \\ Garcia, Marcelo Marcos Morales and Patricia Rieken Macedo Rocco \\ Laboratório de Investigação Pulmonar; Instituto de Biofísica Carlos Chagas Filho; Universidade Federal do Rio de \\ Janeiro; Edifício do Centro de Ciências da Saúde; Bloco G-014; Av. Carlos Chagas Filho, s/n; Cidade \\ Universitária; Ilha do Fundão; 21941902; prmrocco@biof.ufrj.br; Rio de Janeiro - RJ - Brasil
}

\begin{abstract}
Stem cells have a multitude of clinical implications in the lung. This article is a critical review that includes clinical and experimental studies of MedLine and SciElo database in the last 10 years, where we highlight the effects of stem cell therapy in acute respiratory distress syndrome or more chronic disorders such as lung fibrosis and emphysema. Although, many studies have shown the beneficial effects of stem cells in lung development, repair and remodeling; some important questions need to be answered to better understand the mechanisms that control cell division and differentiation, therefore enabling the use of cell therapy in human respiratory diseases.
\end{abstract}

Key words: Bone marrow, fibrosis, repair, acute respiratory distress syndrome, asthma, emphysema

\section{INTRODUCTION}

Stem cells are generally defined as clonogenic cells capable of both self-renewal and multilineage differentiation (Weissman, 2000; Weiss et al., 2008). Whereas embryonic stem cells are derived from mammalian embryos in the blastocyst stage and have the ability to generate any terminally differentiated cell in the body, adult stem cells are part of tissue-specific cells of the postnatal organism into which they are committed to differentiate.

Adult stem cells are classically limited to differentiating into cell types of their tissue origin (Table 1). In this line, some studies (Kotton et al., 2001; Krause et al., 2001; Bonnet, 2003; Ortiz et al., 2003; Anjos-Afonso et al., 2004; Hashimoto et al., 2004; Ishizawa et al., 2004; Yamada et al., 2004; Macpherson et al., 2005; Rojas et al., 2005) have demonstrated a degree of plasticity of adult bone marrow stem cells, with an apparent ability to cross lineage barriers, adopting functional phenotypes of other tissues. This has led to research assessing the potential of adult stem cells in the treatment of various respiratory disorders. A potential advantage of using adult stem cells is that the patient's own cells could be expanded in culture and then reintroduced into the patient. The use of autologous cells would help avoiding some of the problems related to immunologic rejection. The alveolar-capillary membrane is difficult to study, and cell turnover of the alveolar epithelium is poorly understood. However, engraftment by circulating pluripotent cells seems to occur more frequently in the lung than in other organs (Krause et al., 2001). The ability to supplement and potentially manipulate lung repair has important therapeutic implications for currently untreatable lung diseases. The present article critically reviews experimental and clinical biology as well as highlights the effects of cell therapy in some respiratory diseases, such as acute respiratory

\footnotetext{
${ }^{*}$ Author for correspondence
} 
distress syndrome (ARDS), pulmonary fibrosis and emphysema.

Table 1 - Classification of stem cells according to their developmental potential.

\begin{tabular}{cll}
\multicolumn{1}{c}{ Terms } & \multicolumn{1}{c}{ Definition } & \multicolumn{1}{c}{ Example } \\
\hline Totipotents & $\begin{array}{l}\text { Ability to form the embryo and fertilized } \\
\text { trophoblast of the placenta }\end{array}$ & Ocyte or zygote \\
Pluripotents & $\begin{array}{l}\text { Ability to differentiate into almost all cells of the } \\
\text { three germ layers }\end{array}$ & Embryonic stem cells. \\
Multipotents & $\begin{array}{l}\text { Ability to differentiate into a limited range of cell } \\
\text { lineages appropriate to the location }\end{array}$ & Adult, somatic, or tissue-based stem cells \\
Unipotents & Ability to generate one cell type & Type II pneumocytes \\
\hline
\end{tabular}

\section{Embryonic Stem Cells}

Embryonic stem cells (ESCs), isolated from the inner cell mass of a blastocyst cells, are easier to propagate and manipulate in vitro than adult or somatic stem cells. ESCs have been described as potential therapy for some incurable diseases such as: Parkinson's diseases, neurodegenerative diseases, and myocardial infarction (Wu et al., 2007). Many studies have demonstrated success in obtaining several cell types from ESCs, including: cardiomyocytes (Passier et al., 2006), hepatocytes (Cai et al., 2007), pancreatic beta-cells, red blood cells, and airways (Samadikuchaksaraei et al., 2006) and alveolar epithelial cells (Ali et al., 2002; Wang et al., 2007). Several advantages have been associated with ESCs: (1) better integration of cells with receptor tissue, (2) division capacity after deployment, minimizing the number of cells to be transplanted, and (3) the ability to generate one or more somatic adults cell types (Rippon et al., 2006). Despite their great therapeutic potential, ESC therapy presents some limitations: (1) ethical questions surrounding the use of human ESC and (2) the high incidence of tumor formation, depending on the way that immature ESCs are cultured. Additionally, since the risk of rejection is high with ESC, immunosuppressive therapy is necessary yielding potential adverse effects.

\section{ESCs and lung epithelial differentiation}

The potential to derive lung epithelium from ESC in culture has also raised the exciting possibility of future cell-based therapies designed to reconstitute injured lung epithelium. Fewer studies have successfully derived endodermal lineages, such as lung epithelium, from ESC in vitro. Ali and colleagues (2002) demonstrated that the expression of SPC mRNA and protein could be detected after mouse ESC had differentiated into embryonic bodies followed by prolonged culture periods in proprietary "small airway growth medium". These investigators also applied their protocol to generate surfactant protein C (SPC) expression from human ESCs (Samadikuchaksaraei et al., 2006). Subsequent differentiation of mouse ESCs into cells expressing the type I alveolar epithelial marker, aquaporin 5, was also reported (Qin et al., 2005). Additionally, Coraux and colleagues (2005) reported that when ESCs were raised to an airliquid interface, they then gave rise to a fully differentiated airway epithelium containing Clara cells, ciliated cells, and basal cells arranged in a structure strikingly reminiscent of murine airway epithelium in vivo. Taking into account the important patterning signals secreted by developing lung mesenchyma, investigators have also successfully derived SPC + cells by coculturing ESCs with suspensions of digested fetal lung mesenchyma (Van Vranken et al., 2005; Denham et al., 2006). Kubo et al. have significantly advanced the study of ES-derived endoderm by demonstrating that activin A can stimulate nodal signaling in ESCs, thereby enabling, for the first time, the efficient and robust derivation of a definitive endoderm (Kubo et al., 2004). Subsequent reports by this and other groups have confirmed that several endodermal lineages, including liver, lung, intestine, and pancreatic epithelia, can be derived both in vitro and in vivo from ESCs cultured by using this approach (Yasunaga et al., 2005; Rippon et al., 2006). The signaling pathways responsible for this differentiation appear to involve: activin/nodal/transforming growth factor- $\beta$ signaling, canonical WNT signaling activated by wingless-type MMTV integration site family, 
member 3A (WNT3a), and the presence of bone morphogenetic protein 4 (Gadue et al., 2006).

Recently, a pure population of cells resembling type II alveolar epithelium has been isolated from human ESCs engineered to express an antibioticresistance cassette under regulatory control of the SPC promoter (Wang et al., 2007). Under relatively simple culture conditions with serum and puromycin antibiotic, ESCs differentiate, and antibiotic-resistant cells can be selected until a highly pure (>99\%) population of cells expressing a variety of type II alveolar epithelial markers is obtained.

\section{Adult Stem Cells}

After transplantation of the cells into animals that had undergone a conditioning treatment, there was evidence that the cells formed nonlymphohematopoietic tissue, such as muscle fibers, hepatocytes, microglia and astroglia, and neuronal tissue (Krause et al., 2001; Hennessy et al., 2004). In order to prove that stem cells from bone marrow are capable of forming solid-organ tissue cells, purified stem cells with a specific marker had to be transplanted and shown to generate specific functional tissue cells (Anderson et al., 2001). Since progenitor cells derived from bone marrow can reach the target solid organ through the peripheral blood (Wright et al., 2001), determining whether peripheral blood stem cells follow a differentiation pathway specific to solid organs, similar to that seen for stem cells derived from bone marrow, was the logical next step.

\section{Mechanisms for engraftment of bone marrow- derived cells}

There are multiple potential mechanisms by which bone marrow-derived cells could engraft as lung epithelial cells, including transdifferentiation, cell fusion, and paracrine effect. Transdifferentiation is the conversion of one differentiated cell type to another, with or without an intervening cell division. Transdifferentiation belongs to a group of cell type conversions referred to as metaplasias. Stem cells of one tissue type can switch to become those of another metaplasia of stem cells, characteristic of one embryonic germ layer giving rise to cells from another germ layer, and also transdifferentiation between fully differentiated cell types (Tosh and Slack, 2002). However, the transdifferentiation capacity has been questioned and other phenomena are considered responsible for greater adult stem cell proliferative capacity, for example, the cell fusion (Terada et al., 2002).

Cell fusion between mesenchymal stem cells and heat-shocked pulmonary epithelial cells in culture is considered to be very rare (Spees et al., 2003). In this line, Harris and coworkers examined the role of cell fusion in the appearance of marrowderived epithelial cells in the lungs of mice that had undergone bone marrow transplantation after lethal irradiation (Harris et al., 2004). They observed that cell fusion was not required for the appearance of marrow derived epithelial cells. However, recently Krause and colleagues described cell fusion in bone marrow-derived type II pneumocytes (Krause, 2008). Therefore, fusion could be a novel mechanism of cell repair, but the functional implications are currently unclear.

Despite the controversy regarding bone marrow plasticity, most investigators agree that cells derived from the bone marrow appear to play some role during lung repair after injury. Although direct structural contributions to lung epithelial cells may not readily occur, some form of significant supportive or paracrine function probably arises from circulating cells originating from the bone marrow (De Palma et al., 2005). In this line, bone-marrow-derived mesenchymal stem cells (MSC) expanded in culture possess a number of immunomodulatory properties. In a model of bleomycin induced lung injury, intravenous infusions of MSCs demonstrated amelioration of pulmonary fibrosis (Ortiz et al., 2003; Rojas et al., 2005). Potential mechanisms accounting for the immunomodulatory effects of MSCs have been studied ex vivo (Aggarwal and Pittenger, 2005). During co-culturing with a variety of leukocyte subpopulations, for example, MSCs have been shown to secrete factors that modulate TH1 and TH2 phenotypes toward tolerance. In addition, MSCs decrease the secretion of inflammatory cytokines by co-cultured leukocytes and promote the formation of $\mathrm{T}$ regulatory cells. Functional rescue of lung injury has also been demonstrated after infusion of heterogeneous populations of bulk bone marrow or cells derived from cultured fat cells (Shigemura et al., 2006a). These cellbased therapies have been tested in a mouse model of emphysema induced by intratracheal elastase. The mechanism for this protective effect is not known but has been suggested by the authors to involve paracrine effects (such as the secretion of hepatocyte growth factor) rather than direct 
structural repair in view of the rarity of engrafted cells detected (Shigemura et al., 2006b).

\section{Cell Therapy in Respiratory Diseases}

Pulmonary fibrosis, ARDS and emphysema differ substantially in their time course and pathophysiology. One common feature is that the outcome of each seems to be influenced, at least partly, by the ability of the alveolar epithelium to recover after injury. Efficient alveolar epithelial repair may reduce the development of fibrosis. Although pulmonary fibrosis rarely causes longterm sequelae after acute respiratory distress syndrome, the fibrotic process is active when patients need endotracheal intubation, and the extent of subsequent fibrosis is associated with ventilator dependence and mortality (Martin et al., 1995; Rocco and Pelosi, 2008). The injury is more insidious in emphysema (Saetta et al., 1985) and covert in most cases of fibrotic lung disease; the pathogenesis of fibrotic lung disease is now thought to be primarily an aberrant wound-healing response of the lung parenchyma rather than being the result of uncontrolled chronic inflammation (Gross and Hunninghake, 2001).

\section{Stem cells and fibrotic lung disease}

Pulmonary fibrosis, a devastating disease associated to many etiologies, remains without an effective therapy to reverse or delay the natural course of disease. Kotton et al. (2001) evaluated the effects of bone marrow-derived cells (BMCs) in an experimental model of lung fibrosis induced by bleomycin and observed that BMCs migrated to the injured lungs and presented morphologic and functional characteristics of pneumocytes type I (Kotton et al., 2001; Tosh and Slack, 2002). Transplantation of mesenchymal stem cells (MSCs) derived from male BALBc donor mice by adhesion to plastic and subsequent immunodepletion into female C57BL/6 mice was protective against lung fibrosis assayed by total lung hydroxyproline content and inflammation when given immediately after intratracheal bleomycin (Ortiz et al., 2003), suggesting that the use of exogenous cells to repair lung parenchyma might be possible. After bleomycin injury to mice that had received bone-marrow transplantation of eGFP-expressing cells, $80 \%$ of fibroblasts producing type- 1 collagen found at sites of lung fibrosis were of donor origin (Hashimoto et al., 2004). Similarly, after bleomycin administration, human fibrocytes homed to mouse lung in response to CXCL12 chemokine, while bonemarrow derived fibrocytes proliferated (Phillips et al., 2004). In a different model, bone-marrowderived myofibroblasts accumulated in mice subjected to injurious irradiation at sites of alveolitis and pulmonary fibrosis (Epperly et al., 2003). The functional importance of these observations was confirmed when systemic administration of antibody to CXCL12 reduced the accumulation of lung fibrocytes and protected against bleomycin-induced lung fibrosis (Phyllips et al., 2004). Aggregates of MSCs were observed in the lung as early as 1 day after bone-marrow transplantation. In many cases, donor-derived cells persisted and were associated with local inflammation and fibrosis leading to impaired organ function (Anjos-Afonso et al., 2004). Spees et al. (2007) showed that BMCs migrated into developing fibrogenic lesions, differentiated into multiple cell types, and persisted for at least 2.5 weeks after chrysotile asbestos fibers aerolization. However, the optimism of using BMCs to treat pulmonary fibrosis has declined, because of the recent controversial results. Contrary to previous studies, Hashimoto et al. (2004) observed that BMCs differentiated into fibroblasts, the main interstitial collagen source, and Epperly et al. (2003) reported that BMCs originated myofibroblasts, contributing to fibrogenesis.

\section{Stem cells and ARDS}

ARDS, the most severe manifestation of acute lung injury (ALI), is typically described as a stereotyped response to lung injury with transition from alveolar capillary damage to a fibroproliferative phase, independent of initial etiology (Snyder et al., 1990). Most ARDS patients survive the acute initial phase of lung injury and progress to reparation of the lesion, where outcomes may vary from complete recovery to death. Despite recent advances in the management of ALI/ARDS, the mortality remains high (40\%) and for those patients who die, at autopsy, extended pulmonary fibrosis is seen in $55 \%$, suggesting that deregulated repair may contribute to the mortality in these patients (Artigas et al., 1998; Brun-Buisson et al., 2004; Dos Santos, 2008).

It is believed that an effective therapy for the treatment of ALI/ARDS should promote both attenuation of inflammatory response and appropriate repair of lung tissue. In this context, cell therapy emerges as a possible tool for the 
treatment of the pathological events of the disease, or at least for the attenuation of the symptoms. In the past few years, several studies have evaluated the effect of stem cells in ALI/ARDS. These models showed the presence of donor stem cells in the lungs, including epithelial cells types I and II, endothelial cells, fibroblasts and interstitial monocytes (Krause et al., 2001). Stem cells are recruited to the lung due to the inflammatory process triggered by lung injury. In this context, the study of Yamada and colleagues (2004) showed that the inflammatory stimulus promotes the recruitment of progenitor cells from bone marrow into the systemic circulation, with further differentiation in epithelial and endothelial cells.

Stem cells recruitment from bone marrow has been experimentally and clinically studied by the administration of several cytokines, chemokines and chemotherapeutic agents, such as granulocytemonocyte colony-stimulating factor (GM-CSF). GM-CSF has been shown to promote improved gas exchange in patients with severe sepsis, and to restore lung function (Presneill et al., 2002). However, the administration of GM-CSF in healthy subjects in order to recruit stem cells is associated with adverse effects in about 30\% of cases, such as bone pain, headache, general fatigue, and pulmonary complications, including, more frequently ARDS and interstitial pneumonia. GM-CSF, vascular endothelial growth factor (VEGF) and, more effectively, stromal cellderived factor (SDF)-1, appear to be correlated with the recruitment of endothelial progenitor cells, and consequent increase in their number (American Thoracic Society, 2000).

Rojas and colleagues (2005) demonstrated the beneficial effect of BMC administration in a murine model of lung injury induced by bleomycin. Almost the entire lesion was resolved, suggesting that both exogenous and endogenous stem cells play an important role in the repair of lung injury (Rojas et al., 2005). The administration of MSCs also minimized pulmonary inflammation, by reducing the levels of various cytokines, and promoted the release of soluble factors, which recruited stem cells to the site of injury. Other experimental studies have also shown that the use of MSCs in models of lung injury induced by endotoxin, administered intrapulmonary, results in a decrease in mortality (Gupta et al., 2007). The same group showed that the administration of MSCs in ALI induced by lipopolysaccharide (LPS) prevented lung injury and reduced the systemic inflammatory response, by suppressing the production of pro-inflammatory cytokines and stimulating the release of anti-inflammatory cytokines (Xu et al., 2007). Mei and colleagues (2007) observed that, when administered alone, MSCs minimized pulmonary inflammation in a model of ALI induced by LPS. However, the administration of MSCs transfected with angiopoietin-1 resulted in an improvement of the inflammatory process, reducing the levels of various cytokines and chemokines in the bronchoalveolar lavage fluid, leading to a reduction of permeability and consequent leakage of plasma. Moreover, the increased production of angiopoietin-1 by MSCs genetically modified, reduced the production of molecules of adhesion, minimizing the influx of inflammatory cells into the alveolar space and reducing therefore the tissue injury (Mei et al., 2007). Certainly, more studies are necessary to determine which cells are the source of the soluble factors and the effects of the interaction between lung injury and the consequent recruitment of stem cells, with subsequent differentiation into lung cells.

In summary, endogenous and exogenous stem cells have reduced lung injury and its consequent fibrotic process, diminishing systemic and pulmonary inflammation and producing a more appropriate tissue repair through its differentiation in various lung cells. Therefore, cell therapy may be a potential therapeutic tool for treating ALI/ARDS; however, more studies are necessary.

\section{Stem cells and Emphysema}

So far, there is no specific and effective therapy for emphysema (Asia Pacific COPD Roundtable Group, 2005). Stem cells are seen as a possible treatment due to the increasing understanding of their biology and mechanisms. Some studies have assessed the levels of vascular precursor cells in emphysema, and observed the presence of these cells attached to the endothelial surface and within the intimate layer of the pulmonary arteries of patients with pulmonary emphysema. The presence of these cells next to areas of injured endothelium, combined with its relationship with the hypoxic stimulus, suggests that the vascular precursor cells can contribute to the process of repairing the endothelium, as well as to the process of vascular remodeling characteristic of emphysema (Peinado et al., 2006).

The effect of cell therapy in emphysema has not been not been well studied. It is important to have 
a better understanding of cell dynamics of the airways and lung parenchyma, to develop pharmacotherapies and/or effective cell therapies for this respiratory disease.

\section{CONCLUSION}

There is evidence that bone marrow-derived stem cells are able to target areas of the body undergoing injury and contribute to repair. The exact mechanisms are not wholly understood, and different cell species may have different roles in certain situations. Nevertheless, this basic science research is likely to open up new and exciting avenues of pharmacologic, cellular, and genetic therapy for respiratory diseases. Despite recent advances in cell therapy, there are more questions than answers, due to the limited techniques, such as the analysis of recruitment and differentiation of stem cells. Therefore, some questions still need to be answered for the use of cell therapy in respiratory diseases, for example: which cells engraft, since the ideal bone marrow stem cell has not yet been defined? Is the engraftment real or related to artifact? Which factors stimulate or allow the recruitment of these cells into the lung tissue? Where the administration of stem cells should be performed? What are the possible complications or adverse effects triggered by such treatment? Will cells form tumors? Could cells induce damage? It is possible that the answers for those questions may vary depending on the disease studied. Therefore, it is necessary to understand the biology and technology of stem cells, providing a better purification and characterization of bone marrow derived stem cells, determining the mechanisms of recruitment and long-term security of their use. In conclusion, bone marrow derived stem cell therapy may be an effective and safe option in treating respiratory diseases, such as pulmonary fibrosis, ALI/ARDS, and emphysema.

\section{ACKNOWLEDGEMENTS}

The authors are also grateful to, for revisions to the English grammar in the paper.

\section{RESUMO}

As células-tronco têm uma infinidade de implicações clínicas no pulmão. Este artigo é uma revisão crítica que inclui estudos clínicos e experimentais advindos do banco de dados do MEDLINE e SciElo nos últimos 10 anos, onde foram destacados os efeitos da terapia celular na síndrome do desconforto respiratório agudo ou doenças mais crônicas, como fibrose pulmonar e enfisema. Apesar de muitos estudos demonstrarem os efeitos benéficos das células-tronco no desenvolvimento, reparo e remodelamento pulmonar; algumas questões ainda precisam ser respondidas para um melhor entendimento dos mecanismos que controlam a divisão celular e diferenciação, permitindo o uso da terapia celular nas doenças respiratórias.

\section{REFERENCES}

Aggarwal, S., Pittenger, M. F. (2005), Human mesenchymal stem cells modulate allogeneic immune cell responses. Blood, 105(4): 1815-22.

Ali, N. N., Edgar, A. J., Samadikuchaksaraei, A., Timson, C. M., Romanska, H. M., Polak, J. M., Bishop, A. E. (2002), Derivation of type II alveolar epithelial cells from murine embryonic stem cells. Tissue Eng., 8(4): 541-50.

American Thoracic Society. (2000), Idiopathic pulmonary fibrosis: diagnosis and treatment. International consensus statement. American Thoracic Society (ATS), and the European Respiratory Society (ERS). Am J Respir Crit Care Med., 161(2 Pt 1): 646-64.

Anderson, D. J., Gage, F. H., Weissman, I. L. (2001), Can stem cells cross lineage boundaries? Nat Med., 7, 393-395.

Anjos-Afonso, F., Siapati, E. K., Bonnet, D. (2004), In vivo contribution of murine mesenchymal stem cells into multiple cell-types under minimal damage conditions. J Cell Sci., 117(Pt 23), 5655-5664.

Artigas, A., Bernard, G. R., Carlet, J., Dreyfuss, D., Gattinoni, L., Hudson, L., Lamy, M., Marini, J. J., Matthay, M. A., Pinsky, M. R., Spragg, R., Suter, P. M. (1998), The American-European Consensus Conference on ARDS, part 2: Ventilatory, pharmacologic, supportive therapy, study design strategies, and issues related to recovery and remodeling. Acute respiratory distress syndrome. Am J Respir Crit Care Med., 157(4 Pt 1), 1332-1347. 
Asia Pacific COPD Droundtable Group. (2005), Global Initiative for Chronic Obstructive Lung Disease strategy for the diagnosis, management and prevention of chronic obstructive pulmonary disease: an Asia-Pacific perspective. Respirology, 10, 9-17.

Bonnet, D. (2003), Biology of human bone marrow stem cells. Clin Exp Med., 3, 140-149.

Brun-Buisson, C., Minelli, C., Bertolini, G., Brazzi, L., Pimentel, J., Lewandowski, K., Bion, J., Romand, J. A., Villar, J., Thorsteinsson, A., Damas, P., Armaganidis, A., Lemaire, F. (2004), Epidemiology and outcome of acute lung injury in European intensive care units. Results from the ALIVE study. Intensive Care Med., 30, 51-61.

Cai, J., Zhao, Y., Liu, Y., Ye, F., Song, Z., Qin, H., Meng, S., Chen, Y., Zhou, R., Song, X., Guo, Y., Ding, M., Deng, H. (2007), Directed differentiation of human embryonic stem cells into functional hepatic cells. Hepatology, 45, 1229-1239.

Coraux C, Nawrocki-Raby B, Hinnrasky J, Kileztky C, Gaillard D, Dani C, Puchelle E. (2005), Embryonic stem cells generate airway epithelial tissue. Am J Respir Cell Mol Biol., 32, 87-92.

De Palma, M., Venneri, M. A., Galli, R., Sergi Sergi, L., Politi, L. S., Sampaolesi, M., Naldini, L. (2005), Tie2 identifies a hematopoietic lineage of proangiogenic monocytes required for tumor vessel formation and a mesenchymal population of pericyte progenitors. Cancer Cell, 8, 211-226.

Denham, M., Cole, T. J., Mollard, R. (2006), Embryonic stem cells form glandular structures and express surfactant protein $\mathrm{C}$ following culture with dissociated fetal respiratory tissue. Am J Physiol Lung Cell Mol Physiol., 290, L1210- L1215.

Dos Santos, C. C. (2008), Advances in mechanisms of repair and remodelling in acute lung injury. Intensive Care Med., 34, 619-630.

Epperly, M. W., Guo, H., Gretton, J. E., Greenberger, J. S. (2003), Bone marrow origin of myofibroblasts in irradiation pulmonary fibrosis. Am J Respir Cell Mol Biol., 29, 213-224.

Gadue, P., Huber, T. L., Paddison, P. J., Keller, G. M. (2006), Wnt and TGF-beta signaling are required for the induction of an in vitro model of primitive streak formation using embryonic stem cells. Proc Natl Acad Sci U S A, 103, 16806-16811.

Gross, T. J., Hunninghake, G. W. (2001), Idiopathic pulmonary fibrosis. $N$ Engl J Med., 345, 517-525.

Gupta, N., Su, X., Popov, B., Lee, J. W., Serikov, V., Matthay, M. A. (2007), Intrapulmonary delivery of bone marrow-derived mesenchymal stem cells improves survival and attenuates endotoxin-induced acute lung injury in mice. J Immunol., 179, 18551863.

Harris, R. G., Herzog, E. L., Bruscia, E. M., Grove, J. E., Van Arnam, J. S., Krause, D. S. (2004), Lack of a fusion requirement for development of bone marrowderived epithelia. Science, 305(5680), 90-93.
Hashimoto, N., Jin, H., Liu, T., Chensue, S. W., Phan, S. H. (2004), Bone marrow-derived progenitor cells in pulmonary fibrosis. J Clin Invest., 113, 243-252.

Hennessy, B., Korbling, M., Estrov, Z. (2004), Circulating stem cells and tissue repair. Panminerva Med., 46, 1-11.

Ishizawa, K., Kubo, H., Yamada, M., Kobayashi, S., Numasaki, M., Ueda, S., Suzuki, T., Sasaki, H. (2004), Bone marrow-derived cells contribute to lung regeneration after elastase-induced pulmonary emphysema. FEBS Lett., 556, 249-252.

Kotton, D. N., Ma, B. Y., Cardoso, W. V., Sanderson, E. A., Summer, R. S., Williams, M. C., Fine, A. (2001), Bone marrow-derived cells as progenitors of lung alveolar epithelium. Development, 128, 51815188.

Krause, D. S., Theise, N. D., Collector, M. I., Henegariu, O., Hwang, S., Gardner, R., Neutzel, S., Sharkis, S. J. (2001), Multi-organ, multi-lineage engraftment by a single bone marrow-derived stem cell. Cell, 105, 369-377.

Krause, D. S. (2008), Bone marrow-derived cells and stem cells in lung repair. Proc Am Thorac Soc., 5, 323-327.

Kubo, A., Shinozaki, K., Shannon, J. M., Kouskoff, V., Kennedy, M., Woo, S., Fehling, H. J., Keller, G. (2004), Development of definitive endoderm from embryonic stem cells in culture. Development, 131, 1651-1662.

Macpherson, H., Keir, P., Webb, S., Samuel, K., Boyle, S., Bickmore, W., Forrester, L., Dorin, J. (2005), Bone marrow-derived SP cells can contribute to the respiratory tract of mice in vivo. J Cell Sci., 118(Pt 11), 2441-2450.

Martin, C., Papazian, L., Payan, M. J., Saux, P., Gouin, F. (1995), Pulmonary fibrosis correlates with outcome in adult respiratory distress syndrome. A study in mechanically ventilated patients. Chest, 107, 196-200.

Mei, S. H., Mccarter, S. D., Deng, Y., Parker, C. H., Liles, W. C., Stewart, D. J. (2007), Prevention of LPS-induced acute lung injury in mice by mesenchymal stem cells overexpressing angiopoietin 1. PLoS Med., 4, e269.

Ortiz, L. A., Gambelli, F., Mcbride, C., Gaupp, D., Baddoo, M., Kaminski, N., Phinney, D. G. (2003), Mesenchymal stem cell engraftment in lung is enhanced in response to bleomycin exposure and ameliorates its fibrotic effects. Proc Natl Acad Sci $U$ $S$ A, 100, 8407-8411.

Passier, R., Denning, C., Mummery, C. (2006), Cardiomyocytes from human embryonic stem cells. Handb Exp Pharmacol., 174, 101-122.

Peinado, V. I., Ramirez, J., Roca, J., Rodriguez-Roisin, R., Barbera, J. A. (2006), Identification of vascular progenitor cells in pulmonary arteries of patients with chronic obstructive pulmonary disease. Am J Respir Cell Mol Biol., 34, 257-263. 
Phillips, R. J., Burdick, M. D., Hong, K., Lutz, M. A., Murray, L. A., Xue, Y. Y., Belperio, J. A., Keane, M. P., Strieter, R. M. (2004), Circulating fibrocytes traffic to the lungs in response to CXCL12 and mediate fibrosis. J Clin Invest., 114, 438-446.

Presneill, J. J., Harris, T., Stewart, A. G., Cade, J. F., Wilson, J. W. (2002), A randomized phase II trial of granulocyte-macrophage colony-stimulating factor therapy in severe sepsis with respiratory dysfunction. Am J Respir Crit Care Med., 166, 138-143.

Qin, M., Tai, G., Collas, P., Polak, J. M., Bishop, A. E. (2005), Cell extract-derived differentiation of embryonic stem cells. Stem Cells, 23, 712-718.

Rippon, H. J., Polak, J. M., Qin, M., Bishop, A. E. (2006), Derivation of distal lung epithelial progenitors from murine embryonic stem cells using a novel three-step differentiation protocol. Stem Cells, 24, 1389-1398.

Rocco, P. R., Pelosi, P. (2008), Pulmonary and extrapulmonary acute respiratory distress syndrome: myth or reality? Curr Opin Crit Care, 14, 50-55.

Rojas, M., Xu, J., Woods, C. R., Mora, A. L., Spears, W., Roman, J., Brigham, K. L. (2005), Bone marrowderived mesenchymal stem cells in repair of the injured lung. Am J Respir Cell Mol Biol., 33, 145152.

Saetta, M., Shiner, R. J., Angus, G. E., Kim, W. D., Wang, N. S., King, M., Ghezzo, H., Cosio, M. G. (1985), Destructive index: a measurement of lung parenchymal destruction in smokers. Am Rev Respir Dis., 131, 764-769.

Samadikuchaksaraei, A., Cohen, S., Isaac, K., Rippon, H. J., Polak, J. M., Bielby, R. C., Bishop, A. E. (2006), Derivation of distal airway epithelium from human embryonic stem cells. Tissue Eng., 12, 867875.

Shigemura, N., Okumura, M., Mizuno, S., Imanishi, Y., Matsuyama, A., Shiono, H., Nakamura, T., Sawa, Y. (2006a), Lung tissue engineering technique with adipose stromal cells improves surgical outcome for pulmonary emphysema. Am J Respir Crit Care Med., 174, 1199-1205.

Shigemura, N., Okumura, M., Mizuno, S., Imanishi, Y., Nakamura, T., Sawa, Y. (2006b), Autologous transplantation of adipose tissue-derived stromal cells ameliorates pulmonary emphysema. Am J Transplant, 6, 2592-25600.

Snyder, L. S., Hertz, M. I., Harmon, K. R., Bitterman, P. B. (1990), Failure of lung repair following acute lung injury. Regulation of the fibroproliferative response (Part 2). Chest, 98, 989-993.

Spees, J. L., Olson, S. D., Ylostalo, J., Lynch, P. J., Smith, J., Perry, A., Peister, A., Wang, M. Y., Prockop, D. J. (2003), Differentiation, cell fusion, and nuclear fusion during ex vivo repair of epithelium by human adult stem cells from bone marrow stroma. Proc Natl Acad Sci U S A, 100, 2397-2402.
Spees, J. L., Pociask, D. A., Sullivan, D. E., Whitney, M. J., Lasky, J. A., Prockop, D. J., Brody, A. R. (2007), Engraftment of bone marrow progenitor cells in a rat model of asbestos-induced pulmonary fibrosis. Am J Respir Crit Care Med, 176, 385-394.

Terada, N., Hamazaki, T., Oka, M., Hoki, M., Mastalerz, D. M., Nakano, Y., Meyer, E. M., Morel, L., Petersen, B. E., Scott, E. W. (2002), Bone marrow cells adopt the phenotype of other cells by spontaneous cell fusion. Nature, 416, 542-545.

Tosh, D., Slack, J. M. (2002), How cells change their phenotype. Nat Rev Mol Cell Biol., 3, 187-194.

Van Vranken, B. E., Romanska, H. M., Polak, J. M., Rippon, H. J., Shannon, J. M., Bishop, A. E. (2005), Coculture of embryonic stem cells with pulmonary mesenchyme: a microenvironment that promotes differentiation of pulmonary epithelium. Tissue Eng., 11, 1177-1187.

Wang, D., Haviland, D. L., Burns, A. R., Zsigmond, E., Wetsel, R. A. (2007), A pure population of lung alveolar epithelial type II cells derived from human embryonic stem cells. Proc Natl Acad Sci U S A, 104, 4449-4454.

Weiss, D. J., Kolls, J. K., Ortiz, L. A., PanoskaltsisMortari, A., Prockop, D. J. (2008), Stem cells and cell therapies in lung biology and lung diseases. Proc Am Thorac Soc., 5, 637-667.

Weissman, I. L. (2000), Stem cells: units of development, units of regeneration, and units in evolution. Cell, 100, 157-168.

Wright, D. E., Wagers, A. J., Gulati, A. P., Johnson, F. L., Weissman, I. L. (2001), Physiological migration of hematopoietic stem and progenitor cells. Science, 294(5548), 1933-1936.

Wu, D. C., Boyd, A. S., Wood, K. J. (2007), Embryonic stem cell transplantation: potential applicability in cell replacement therapy and regenerative medicine. Front Biosci., 12, 4525-4535.

Xu, J., Woods, C. R., Mora, A. L., Joodi, R., Brigham, K. L., Iyer, S., Rojas, M. (2007), Prevention of endotoxin-induced systemic response by bone marrow-derived mesenchymal stem cells in mice. Am J Physiol Lung Cell Mol Physiol., 293, L131-L141.

Yamada, M., Kubo, H., Kobayashi, S., Ishizawa, K., Numasaki, M., Ueda, S., Suzuki, T., Sasaki, H. (2004), Bone marrow-derived progenitor cells are important for lung repair after lipopolysaccharideinduced lung injury. J Immunol., 172, 1266-1272.

Yasunaga, M., Tada, S., Torikai-Nishikawa, S., Nakano, Y., Okada, M., Jakt, L. M., Nishikawa, S., Chiba, T., Era, T., Nishikawa, S. (2005), Induction and monitoring of definitive and visceral endoderm differentiation of mouse ES cells. Nat Biotechnol., 23, 1542-1550.
Received: August 22, 2008; Revised: September 02, 2008; Accepted: September 04, 2008. 